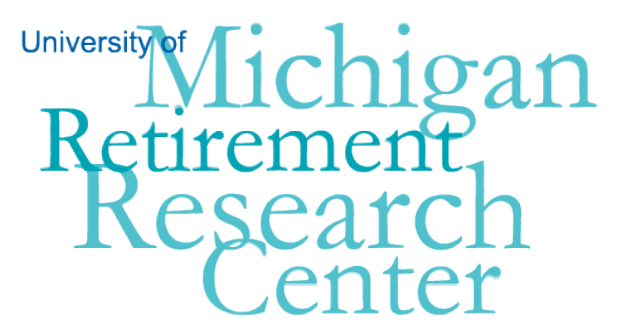

Working Paper

WP 2012-279

\title{
Personality Traits and Economic Preparation for Retirement
}

Michael D. Hurd, Angela Lee Duckworth, Susann Rohwedder and David R. Weir

\begin{tabular}{l|l}
\hline $\mathrm{M}$ & $\mathrm{R}$ \\
\hline $\mathrm{R}$ & $\mathrm{C}$ \\
\hline
\end{tabular}

Project \#: UM12-11 



\title{
Personality Traits and Economic Preparation for Retirement
}

\author{
Michael D. Hurd \\ RAND
}

Angela Lee Duckworth

University of Pennsylvania

Susann Rohwedder

RAND

David R. Weir

University of Michigan

September 2012

\author{
Michigan Retirement Research Center \\ University of Michigan \\ P.O. Box 1248 \\ Ann Arbor, MI 48104 \\ www.mrrc.isr.umich.edu
}

(734) 615-0422

\section{Acknowledgements}

This work was supported by a grant from the Social Security Administration through the Michigan Retirement Research Center (Grant \# 5 RRC08098401-04-00). The findings and conclusions expressed are solely those of the author and do not represent the views of the Social Security Administration, any agency of the Federal government, or the Michigan Retirement Research Center. 



\title{
Personality Traits and Economic Preparation for Retirement
}

\begin{abstract}
This paper assesses the effects of personality traits on economic preparation for retirement, wealth accumulation, and consumption, among persons 66 to 69 years of age. Among the five chief personality traits of neuroticism, extroversion, agreeableness, conscientiousness, and openness, we focus most on conscientiousness. We find levels of adequate economic preparation for retirement ranging from 29 percent to 90 percent and that conscientiousness positively affects the proportion of persons adequately prepared for retirement, while neuroticism negatively affects it. Both consumption and wealth increase with conscientiousness but wealth increases faster, indicating that more conscientious persons save more out of retirement resources.
\end{abstract}

\section{Authors’ Acknowledgements}

This research was supported by a grant from the U.S. Social Security Administration (SSA) as part of the Retirement Research Consortium (RRC). The findings and conclusions are solely those of the authors and do not represent the views of SSA, any agency of the Federal Government, the NBER Retirement Research Center, CRR, or MRRC. Additional funding for data development and prior model development came from the National Institute on Aging. Thanks to Joanna Carroll for excellent programming assistance. 


\section{Background}

Personality traits, defined as patterns of thinking, feeling, and behaving which are relatively stable across time and situations, have recently been recognized as important predictors of economic outcomes (Borghans, Duckworth, Heckman, \& Ter Weel, 2008; Paunonen, 2003). The "Big Five" taxonomy of personality traits, encompassing neuroticism, extroversion, agreeableness, conscientiousness, and openness, is now widely accepted as describing the organization of personality at the broadest level of abstraction. This taxonomy has been replicated across cultures (John \& Srivastava, 1999) and developmental stages of the life course (Soto, John, Gosling, \& Potter, 2008).

The personality psychology literature has identified conscientiousness as the personality trait most influencing academic achievement (Poropat, 2009), job performance (Roberts, Kuncel, Shiner, Caspi, \& Goldberg, 2007), marital stability (Roberts et al., 2007), physical health (Hampson, Goldberg, Vogt, \& Dubanoski, 2006; Hampson, in press), and longevity (Martin, Friedman, \& Schwartz, 2007).

Consistent with these findings, Duckworth et al. (2012) found conscientiousness to be more strongly associated with both lifetime earnings and wealth conditional upon earnings than any other of the Big Five traits. These associations remained significant even when controlling for years of education, demographics, and measures of cognitive ability. These results imply that more conscientious individuals both have greater lifetime earnings and save more of those earnings prior to retirement.

This research addresses variation in saving behavior in years following retirement as a function of variation in measures of personality. Our method is to find whether personality traits are associated with better economic preparation for retirement where preparation is defined to be having a low risk of outspending resources prior to death. For example, under the hypothesis that conscientious individuals are better at determining the optimal level of spending and are better able to adjust their spending to that level, we would expect them to have a lower risk of outspending their resources than less conscientious individuals.

This research advances previous research linking economic outcomes to personality traits because it accurately compares spending levels with economic resources. While informative, previous analyses of spending levels or of saving rates across personality types did not control for life-cycle effects and hence could be inaccurate. For example, some conscientious persons in their 60 s may have already saved adequately and so their optimal saving rate could be close to zero. Persons with reduced life expectancy, which may be correlated with personality traits, should have reduced saving rates. Furthermore, it is necessary to account for pension and Social Security resources, which is difficult to do prior to retirement. This paper explores, conditional on economic resources and accounting for life-cycle effects, whether the 
level of consumption (and hence the saving rate) varies with personality traits. It quantifies shortfalls or excesses in consumption as a function of those traits.

\section{Data}

We use data from the Health and Retirement Study (HRS) for this analysis. The HRS is a panel survey of Americans at least 50 years of age and their spouses with questions on income, work, assets, pension plans, health insurance, disability, physical health and functioning, cognitive functioning, and health-care expenditures. In addition, the HRS in recent years has collected an adjective measure of the Big Five personality traits. Specifically, in 2006, about half the HRS sample (chosen at random) received the 2006 Psychosocial Leave-Behind Participant Lifestyle Questionnaire (see Appendix). In 2008 the other half of the HRS respondents received this questionnaire. An estimated 14,500 individuals completed this paperand-pencil measure (about 90\% response rate for those assigned to a face-to-face interview). Because not all HRS participants completed the psychosocial questionnaire, we use survey weights in our analyses to adjust for sample selection.

\section{Measures of personality traits}

The Big Five measure (Lachman \& Bertrand, 2001) included five adjective markers of Conscientiousness: organized, responsible, hardworking, careless (reversed for purposes of analysis), and thorough. Respondents rated themselves on these on a 4-point scale from 1 = "not" to 4 = "a lot." The Emotional Stability scale (neuroticism) included four items using the same scale: moody (reversed), nervous (reversed), calm, and worrying (reversed). Both scales were reliable, with alphas above 70 (Roberts, Smith, \& Jackson, 2009). We include the other Big Five scales for extroversion, agreeableness, and openness to experience in our analyses but expect them to have less influence on consumption and savings.

\section{Economic data}

We base our economic analyses on data from the HRS and data from the Consumption and Activities Mail Survey (CAMS). In September 2001, the CAMS wave 1 was mailed to 5,000 households selected at random from households that participated in the 2000 wave of the HRS. In couple households, it was sent to one of the two spouses at random. In September 2003 and October 2005, 2007 and 2009, CAMS waves 2-5 were sent to the same households. 
CAMS asked respondents about their spending in each of 32 categories representing nearly all household spending. The rates of item nonresponse were small, and some values could be imputed to zero with considerable confidence, given information in the linked HRS data. The resulting spending levels are close to totals indicated by the Consumer Expenditure Survey (CEX) for persons between 55 and 74 years of age, but CAMS shows higher spending levels than the CEX for persons 75 years of age or older.

\section{Model of life-cycle consumption}

In prior work, Hurd and Rohwedder (2008) estimated life-cycle consumption paths for couples and for single persons based on CAMS panel data. Besides accounting for age and marital status, their estimations account for differential mortality by sex and by education. We use their model and estimations in this research. Beginning with the level of spending at ages $66-69$, we simulate the consumption path of single persons until death, which happens at random according to probabilities that are specific to age, sex, marital status and education. We count the fraction of the simulations in which an individual dies before running out of wealth. If that fraction is high ( $95 \%$ or greater in this paper), we conclude the person is adequately prepared for retirement. The evaluation involves comparing economic resources with needs as reflected in initial consumption. We account for consumption of health-care services on average in the CAMS data. If there were no spending risk, out-of-pocket spending for health care would need no further treatment. But because of the existence of spending risk, a single person's actual consumption of health-care services will differ from the average level by a spending shock that has an expected value of zero, but could be quite large. We construct that shock from HRS data on out-ofpocket spending for health-care services.

Couples will follow a couple's consumption path as long as both spouses are alive. After the death of one spouse, the surviving spouse will follow a single person's consumption path. The surviving spouse's level of consumption will depend on returns-to-scale in consumption by the couple. We use the poverty line to determine the appropriate returns-to-scale parameter. Poverty-level income for a couple is 1.26 times that for a single person. This implies that consumption by the surviving spouse should be $79 \%$ of consumption by the couple to equate effective consumption. We use this value in the simulations of this paper.

In addition to longevity and health-care spending risk the models take into account different tax rates for Social Security income and for other income, taxes on retirement accounts, and differential mortality. 
We consider a person adequately prepared for retirement if he or she has at least a 95 percent probability of dying with unconsumed wealth.

\section{Results}

We first simulate consumption and wealth paths and find economic preparation for retirement. Table 1 shows these results. We find overall that about $80 \%$ of married persons and $55 \%$ of single persons are adequately prepared for retirement. Yet there is substantial variation by education level, and, in the case of single persons, by sex. In particular just $29 \%$ of single women who lack a high school education are adequately prepared.

The main goal of this paper is to relate preparation for retirement to personality traits. Thus, we classify each person as either adequately prepared or not adequately prepared, and then we estimate the effect of personality traits on the probability of being prepared, controlling for education and marital status.

Table 2 shows the effect of personality traits among married persons on the probability of being economically prepared for retirement. ${ }^{1}$ In the estimations that do not control for education, conscientiousness has a significant positive effect on economic preparation for retirement for husbands: the marginal effect is that an increase in conscientiousness of one unit (on a scale of 1-4) increases the probability of preparation for retirement by 0.169 . Figure 1 shows that a change on one unit is equivalent to a movement in the distribution of conscientiousness in the population of married men from about the $20^{\text {th }}$ to the $80^{\text {th }}$ percentile. This is a large change when compared with the variation in preparation by education level. For example, it is the same as the variation between married men lacking a high school degree and married men with a college education, as shown in Table 1. Among wives, neuroticism has a significant negative effect on preparation: a one-unit change in neuroticism reduces the probability of being economically prepared for retirement by 0.096 . No other coefficients are significant in the estimations for married persons. When education is included as a predictor, as in Table 3, the effects of neuroticism and conscientiousness are reduced, but not substantially. Nevertheless, the effects of increasing education are greater than those of any personality trait, including neuroticism and conscientiousness, a result we might have anticipated from the results in Table 1.

Table 4 shows the effects of personality traits on preparations for retirement among single persons. Neuroticism negatively affects preparation for retirement among both single males and single

\footnotetext{
${ }^{1}$ For simplicity of exposition, we will use the word "effects" when discussing the magnitudes of estimates relating personality measures to outcomes such as wealth while recognizing that reverse causality could be quantitatively important.
} 
females; extroversion negatively affects preparation for retirement among single males. No other behavioral trait has a significant effect on preparations for retirement among single persons. Furthermore, as Table 5 shows, including levels of educational attainment in the model for single persons substantially eliminates the effects of personality traits. Put another way, among single persons, and in contrast to our findings among married persons and the overall sample, conscientiousness does not predict economic preparation for retirement. Our results may be due in part to small sample sizes: the results for single men are based on just 124 observations (for whom even educational effects in Table 5 are not significant) and for single women on just 418 observations. But our results may also reflect complex life histories for divorced or widowed persons who accumulated assets with a partner who may have had different personality traits.

Adequate preparation for retirement as measured in this paper is the result of balancing economic resources against consumption levels. Someone may have accumulated few assets but, if properly adjusting consumption, the risk of outspending assets prior to death may be no larger than that for a person who has accumulated substantial assets but consumes at a correspondingly higher level. The implication is that the effect of personality may operate through economic resources or through consumption levels or both. To investigate the magnitudes of these separate channels, we separately estimate the effects of personality traits on economic resources and on consumption. Combining them will show the effects on saving.

Table 6 shows the results from regressing the logarithm of total economic resources on personality traits for married persons, while Table 7 shows the results of regressing economic resources on both personality traits and education. Similarly, Table 8 shows the results of regressing the logarithm of total economic resources on personality traits for single persons, while Table 9 shows the results of regressing economic resources on both personality traits and education. In these tables, economic resources are the sum of assets, expected future earnings, and the expected present value of Social Security benefits and pension income. Thus, our measure is a complete measure of economic resources that the individual or couple can expect to receive over the remainder of their life. We will call this "wealth."

Table 6 shows that neuroticism negatively affects wealth among married persons, particularly females, while conscientiousness positively affects wealth among both males and females, and openness positively affects wealth among females. In particular, a one-unit increase in conscientiousness among married males is associated with a 0.624 increase in log wealth, which corresponds to an increase in wealth of about $87 \%$. The effect among wives is smaller, although still substantial. Among married women, a one-unit increase in neuroticism is associated with a decrease in log wealth of 0.238 . Table 7 shows these effects are reduced when education is included but they still remain significant. 
Tables 8 and 9 show similar results among singles. Table 8 shows conscientiousness increases wealth by about $30 \%$, especially for females, and openness increases wealth for females by an even greater amount. Table 9 shows these effects disappear when education is added to the model.

Tables 10 through 12 show the effects of personality traits on initial consumption of married persons. Table 10 shows conscientiousness and openness having positive effects on initial consumption for all respondents. When education is added to the model, as Table 11 shows, conscientiousness has a positive effect on consumption for married males, but no other personality trait has a statistically significant effect on consumption for males or females. Adding total resources to the equation eliminates the significance of personality traits on consumption for married persons, and reduces substantially the effects of education on consumption.

Tables 13 through 15 show the effects of personality traits on initial consumption of single persons. Table 13 shows openness has a positive effect on consumption, particularly for single females. This effect, however disappears when education is added to the model, as Table 14 shows, and some education effects disappear when wealth is added to the model, as Table 15 shows.

The effects of wealth on consumption are for both married and single persons rather low, ranging from 0.18 to 0.35 , as Tables 12 and 15 show. The interpretation of these estimates is the elasticity of consumption with respect to wealth. Because we have a measure of total rest-of-lifetime resources we would expect these coefficients to approach 1.0. The fact that they are substantially less than 1.0 likely reflects measurement error: the difficulties of obtaining accurate measures of wealth are well known.

\section{Effect of personality on saving}

We have found that several personality traits affect both total economic resources and consumption. These relationships could be due to a direct relationship between personality traits and economic resources. They might also be due to the well-known direct relationship between economic resources and consumption, or to a direct relationship between personality traits and consumption, holding economic resources constant. We cannot separate these possible explanations based on data prior to retirement, but, based on the results in Tables $6-15$, we can separate them after retirement.

We have estimated $\frac{d \ln (c)}{d p}=\alpha_{c}$ where $p$ is a personality trait and $c$ is initial consumption; these results are in Tables 10-15. We have estimated $\frac{d \ln (w)}{d p}=\alpha_{w}$ where $w$ is wealth, and we have 
displayed those results in Tables 6-9. Based on these estimates, we can find the effect of $p$ on saving out of $w$ or equivalently on the consumption ratio $\frac{c}{w}$. Write

$$
\frac{d(c / w)}{d p}=\frac{1}{w} \frac{d c}{d p}-\frac{c}{w^{2}} \frac{d w}{d p}=\frac{c}{w}\left(\alpha_{c}-\alpha_{w}\right)
$$

which implies that

$$
\frac{1}{c / w} \frac{d(c / w)}{d p}=\alpha_{c}-\alpha_{w}
$$

Thus, when multiplied by 100, the difference between the consumption and the wealth coefficients is the percentage change in the rate of consumption out of wealth due to a change in personality.

Table 16 shows these coefficients for married persons, and Table 17 shows them for single persons, with both tables showing results for models that exclude and include education. The columns labeled "spending - wealth" show the difference, which has the interpretation of $\alpha_{c}-\alpha_{w}$. Among married men, a unit increase in conscientiousness increases spending (consumption), but increases wealth by much more so that the rate of consumption out of wealth declines by about $34 \%$; said differently, the

ratio $\frac{c}{w}$ declines by $34 \%$ (not percentage points). When education is included, conscientiousness leads to a smaller but substantial decline of $19 \%$. Among married women, conscientiousness also leads to a reduction in $\frac{C}{w}$ but of a smaller amount. Neuroticism leads to an increase in $\frac{C}{w}$.

Among single persons, conscientiousness is associated with a reduction in $\frac{c}{w}$ of about $20 \%$.

Extroversion leads to an increase in $\frac{c}{w}$ of about the same percentage for males, but only when education is excluded for females.

\section{Conclusions}

We have found that individuals with higher levels of conscientiousness are more likely to be economically prepared for retirement. Because of how we define economic preparation, adequacy results from a balancing of economic resources with spending levels. For example, among single males, the probability of adequate preparation is approximately constant across education levels even though economic resources vary greatly with education because spending varies similarly. When we estimated the effects of conscientiousness on economic resources and on spending separately, we found that resources increase at a greater rate than spending, which implies that the saving rate increases with conscientiousness. Thus, conscientious individuals are able to accumulate greater resources both because 
of greater earnings, as shown in Duckworth et al. (2012), and because of high saving. Whether they also are better at earning higher rates of return on their savings via better portfolio management is beyond the scope of this paper but is worthy of future research. 


\section{APPENDIX}

Measurement of personality traits

The HRS measurement is taken from the following source:

Lachman, M. E., \& Weaver, S. L. (1997). Midlife Development Inventory (MIDI) personality scales:

Scale construction and scoring. Unpublished Technical Report. Brandeis

University.(http://www.brandeis.edu/projects/lifespan/scales.html)

Respondents are asked to self-rate how the following words apply to them.

Q33a Outgoing
Q33b Helpful
Q33c Moody
Q33d Organized
Q33e Friendly
Q33f Warm
Q33g Worrying
Q33h Responsible
Q33i Lively
Q33j Caring
Q33k Nervous
Q331 Creative
Q33m Hardworking
Q33n Imaginative
Q33o Softhearted
Q33p Calm
Q33q Intelligent
Q33r Curious
Q33s Active
Q33t Careless
Q33u Broad-minded
Q33v Sympathetic


Q33w Talkative

Q33x Sophisticated

Q33y Adventurous

Q33z Thorough

Coding: $1=$ A lot, $2=$ Some, $3=$ A little, $4=$ Not at all

Scaling: Reverse-code all items EXCEPT Q33p and Q33t, and average the scores for items within sub-dimensions for

Neuroticism (Q33c, Q33g, Q33k, Q33p),

Extroversion (Q33a, Q33e, Q33i, Q33s, Q33w),

Agreeableness (Q33b, Q33f, Q33j, Q33o, Q33v),

Conscientiousness (Q33d, Q33h, Q33m, Q33t, Q33z), and

Openness to Experience (Q331, Q33n, Q33q, Q33r, Q33u, Q33x, Q33y).

Set the final score to missing if more than half of the items have missing values within each sub-dimension. 


\section{References}

Borghans, L., Duckworth, A. L., Heckman, J. J., \& Ter Weel, B. (2008). The economics and psychology of personality traits. Journal of Human Resources.

Duckworth, Angela L, David Weir, Eli Tsukayama, and David Kwok, (2012), Who does well in life? Conscientious adults excel in both objective and subjective success, manuscript.

Hampson, S. E., Goldberg, L. R., Vogt, T. M., \& Dubanoski, J. P. (2006). Forty Years On: Teachers' Assessments of Children's Personality Traits Predict Self-Reported Health Behaviors and Outcomes at Midlife. Health Psychology, 25, 57-64.

Hampson, S. E. F., Howard S. (in press). Personality and health: A life span perspective. In R. W. R. O. P. John, \& L. Pervin (Ed.), The Handbook of Personality (3rd ed.). New York Guilford.

Hurd, M. D. \& Rohwedder, S. (2008). “Adequacy of Economic Resources in Retirement and Returns-toscale in Consumption," Michigan Retirement Research Center Working Paper WP 2008-174, May 2008

Hurd, M. D. \& Rohwedder, S. (2012). Economic Preparation for Retirement. In D. A. Wise (Ed.), Investigations in the Economics of Aging, University of Chicago Press, 77-113 (also available as NBER working paper no. 17203, July 2011).

John, O. P., \& Srivastava, S. (1999). The Big Five Trait taxonomy: History, measurement, and theoretical perspectives. In L. A. Pervin \& O. P. John (Eds.), Handbook of personality: Theory and research (2nd ed.). (pp. 102-138). New York, NY, US: Guilford Press.

Lachman, M. E., \& Bertrand, R. M. (2001). Personality and the self in midlife. In M. E. Lachman (Ed.), Handbook of midlife development (pp. 279-309). New York: Wiley.

Martin, L. R., Friedman, H. S., \& Schwartz, J. E. (2007). Personality and mortality risk across the life span: The importance of conscientiousness as a biopsychosocial attribute. Health Psychology, 26, 428-436.

Paunonen, S. V. (2003). Big Five factors of personality and replicated predictions of behavior. Journal of Personality and Social Psychology, 84, 411-422.

Poropat, A. E. (2009). A meta-analysis of the five-factor model of personality and academic performance. Psychological Bulletin, 135, 322-338.

Roberts, B. W., Kuncel, N. R., Shiner, R., Caspi, A., \& Goldberg, L. R. (2007). The power of personality: The comparative validity of personality traits, socioeconomic status, and cognitive ability for predicting important life outcomes. Perspectives on Psychological Science, 2, 313-345.

Roberts, B. W., Smith, J., Jackson, J. J., \& Edmonds, G. (2009). Compensatory Conscientiousness and Health in Older Couples. Psychological Science. 
Soto, C. J., John, O. P., Gosling, S. D., \& Potter, J. (2008). The developmental psychometrics of big five self-reports: Acquiescence, factor structure, coherence, and differentiation from ages 10 to 20.

Journal of Personality and Social Psychology, 94, 718-737. 
Figure 1. Cumulative distribution of personality traits. Married persons Neuroticism

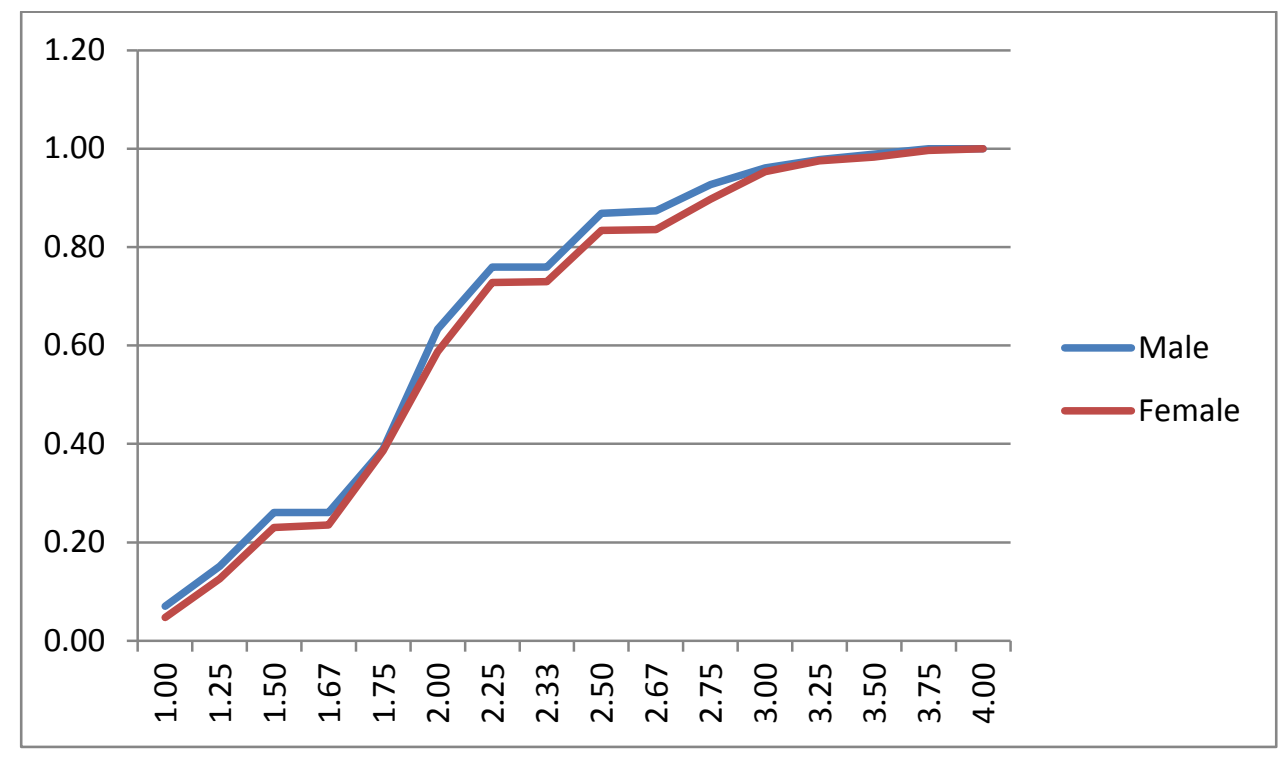

\section{Extroversion}

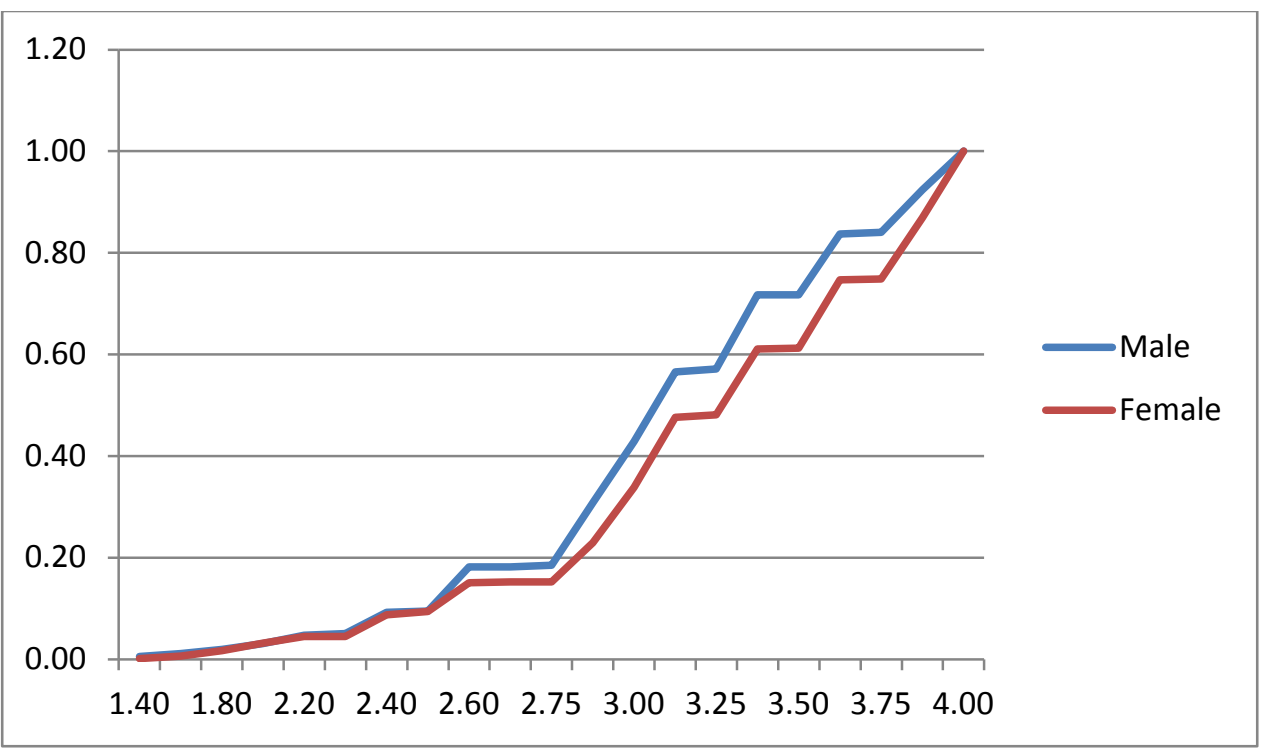


Agreeableness

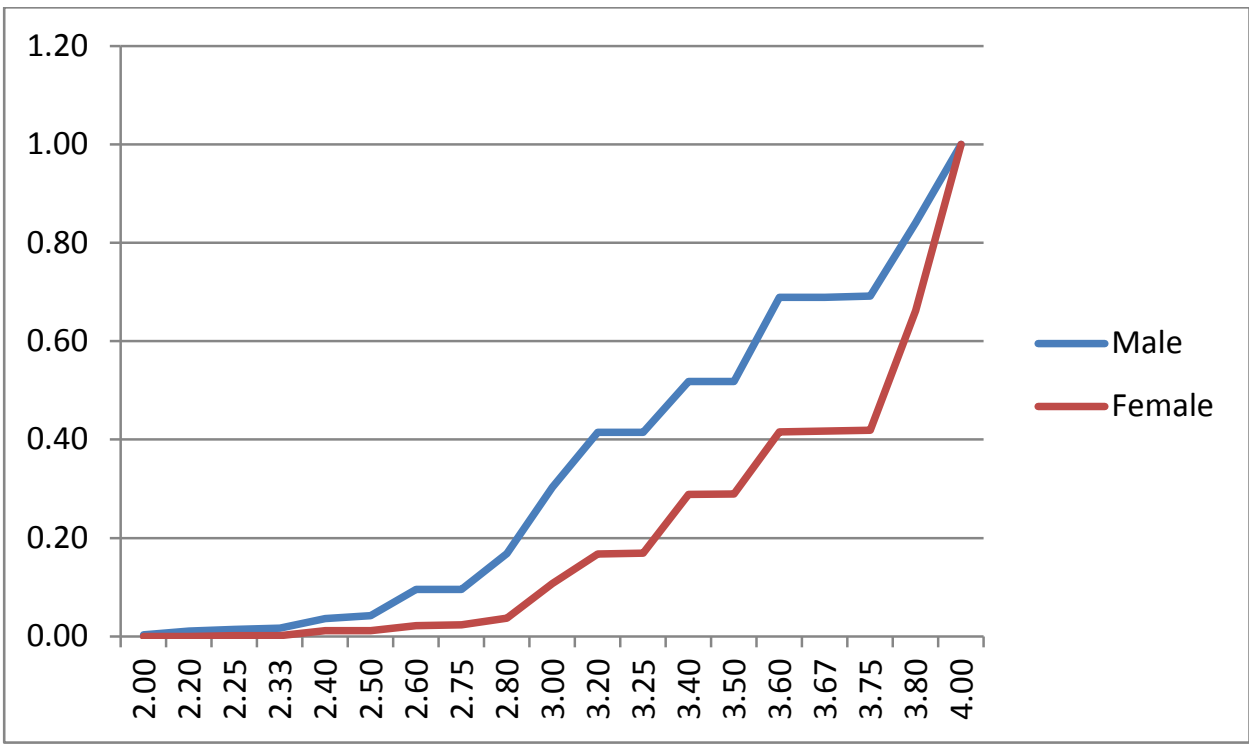

\section{Conscientiousness}

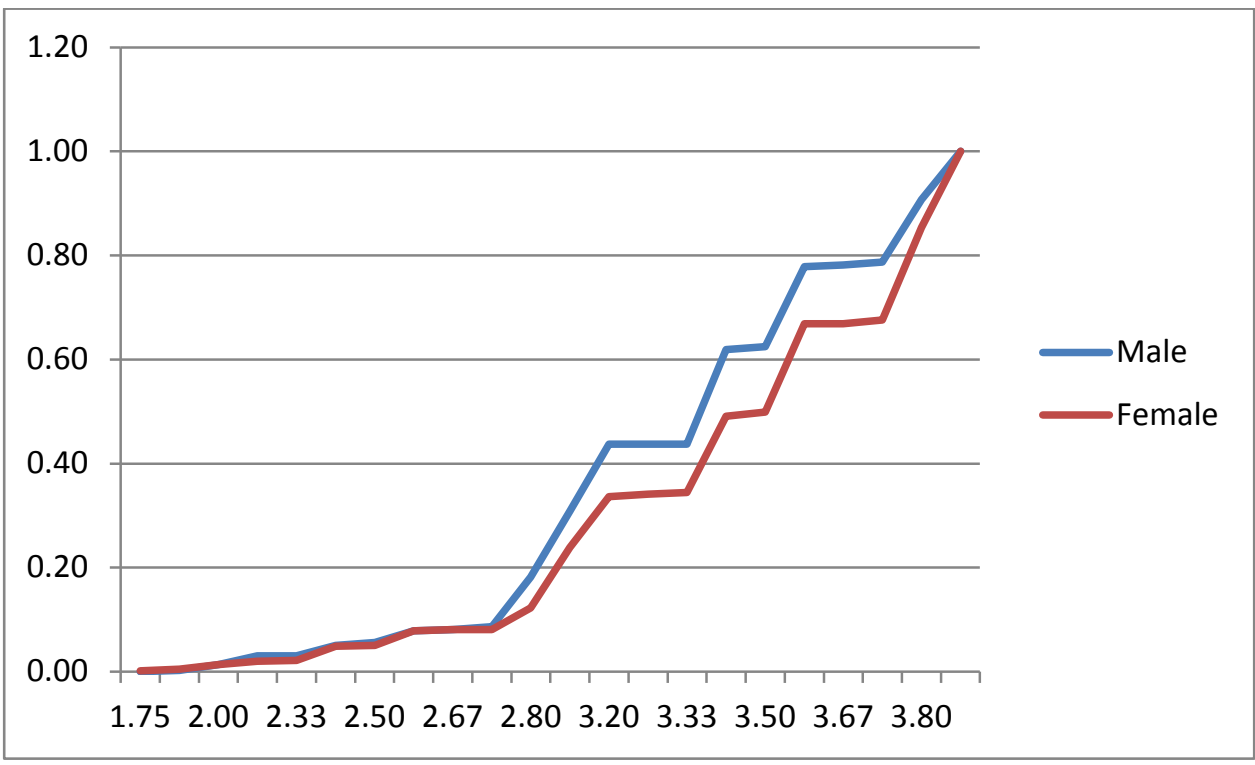


Openness

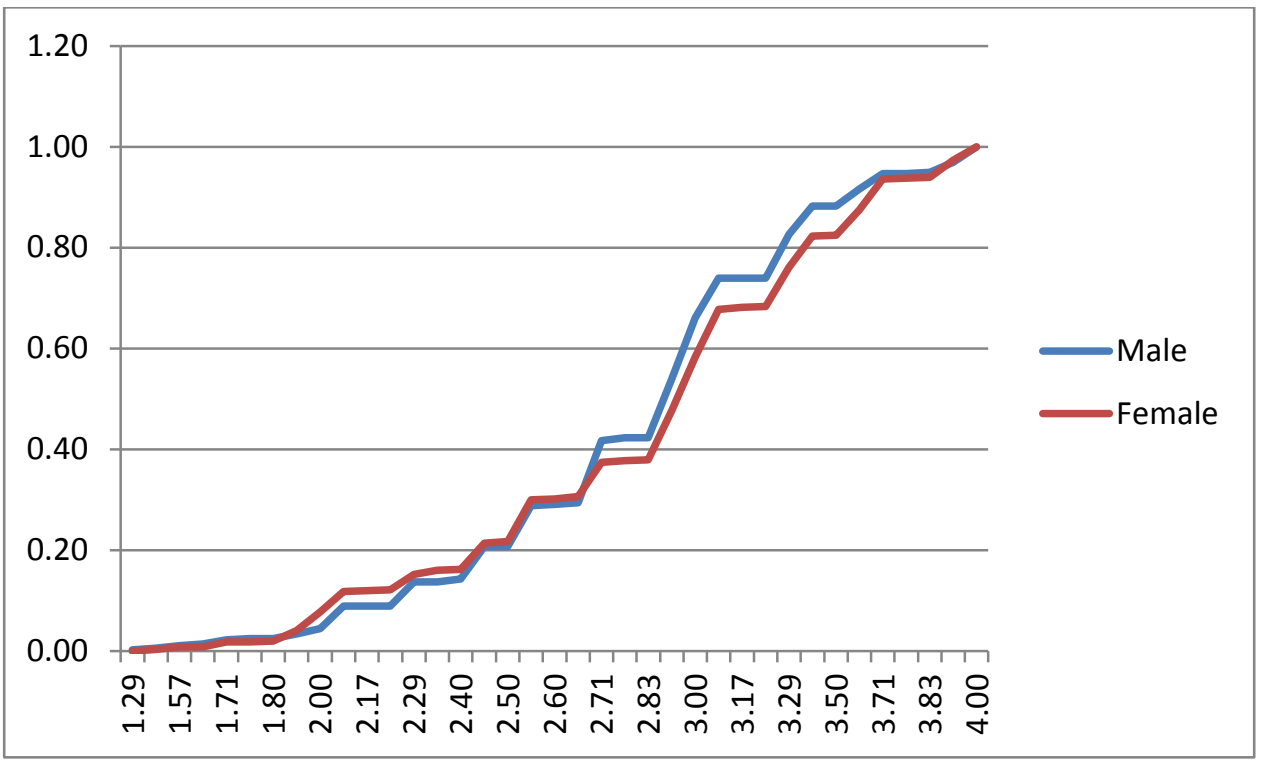


Figure 2. Cumulative distribution of personality traits. Single persons Neuroticism

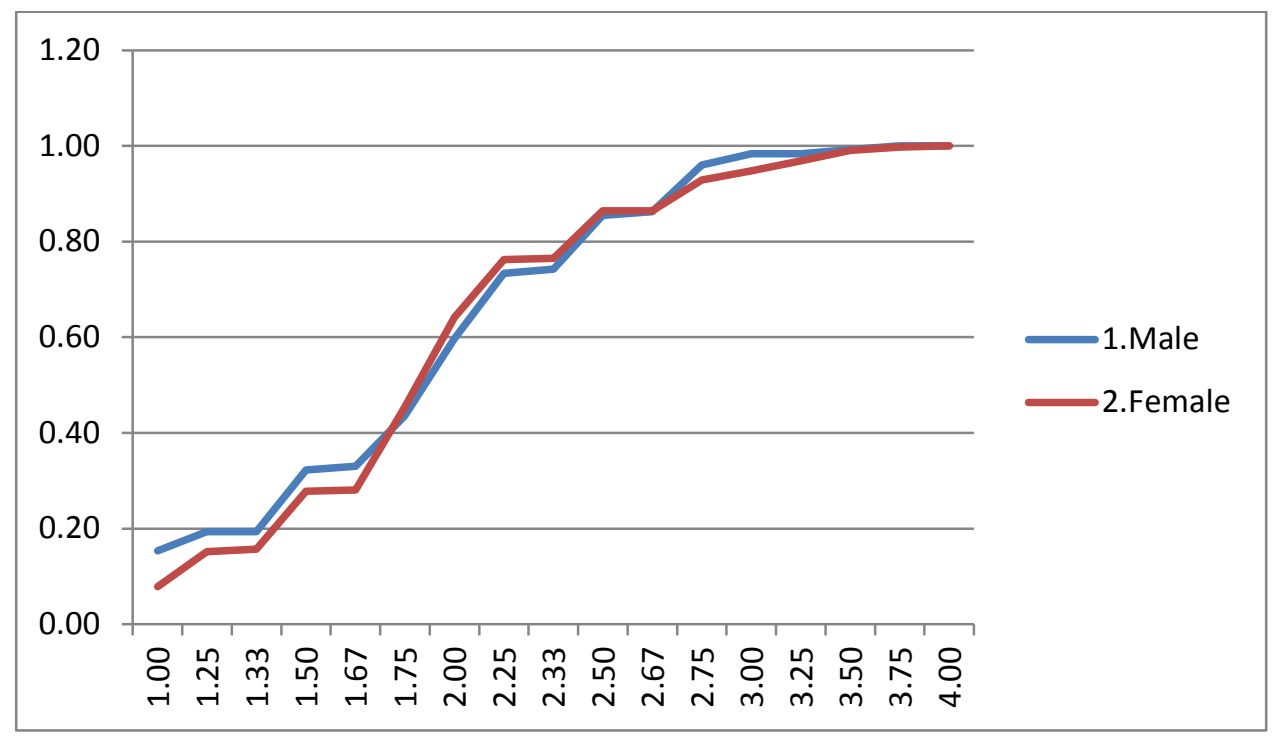

Extroversion

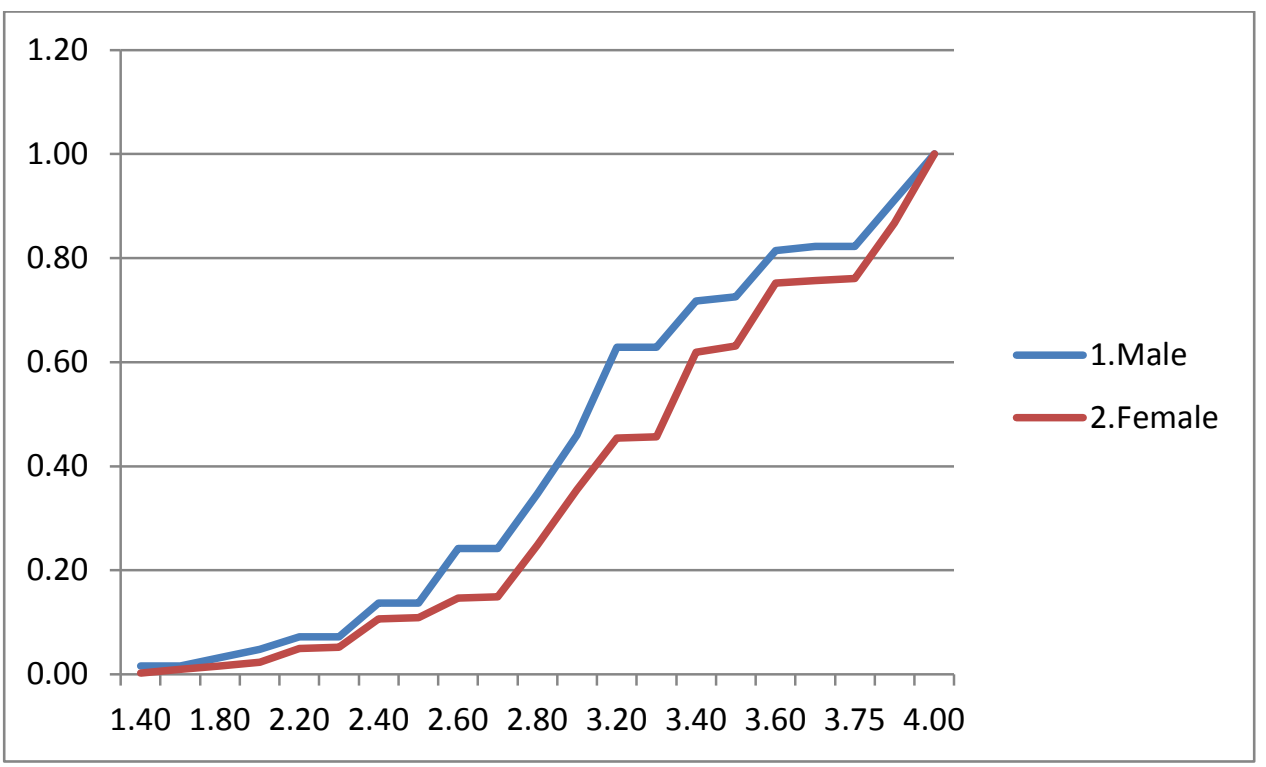


Agreeableness

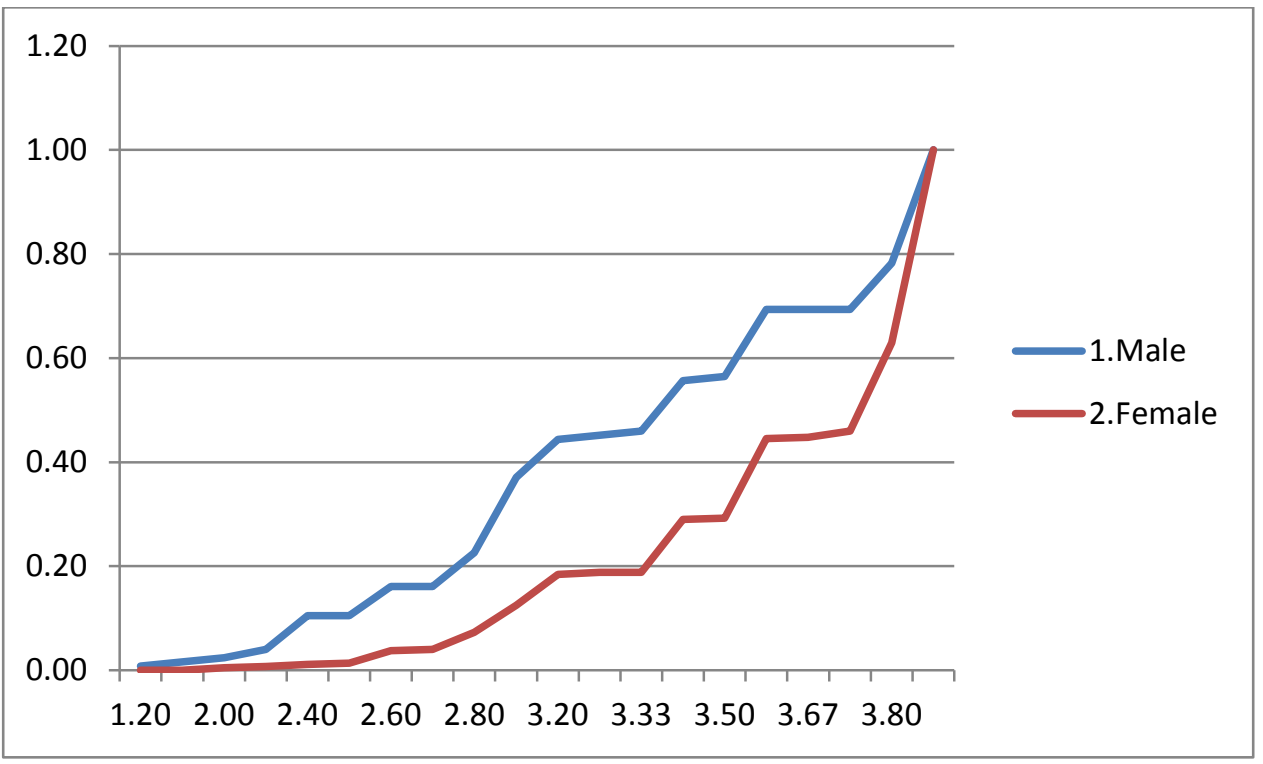

\section{Conscientiousness}

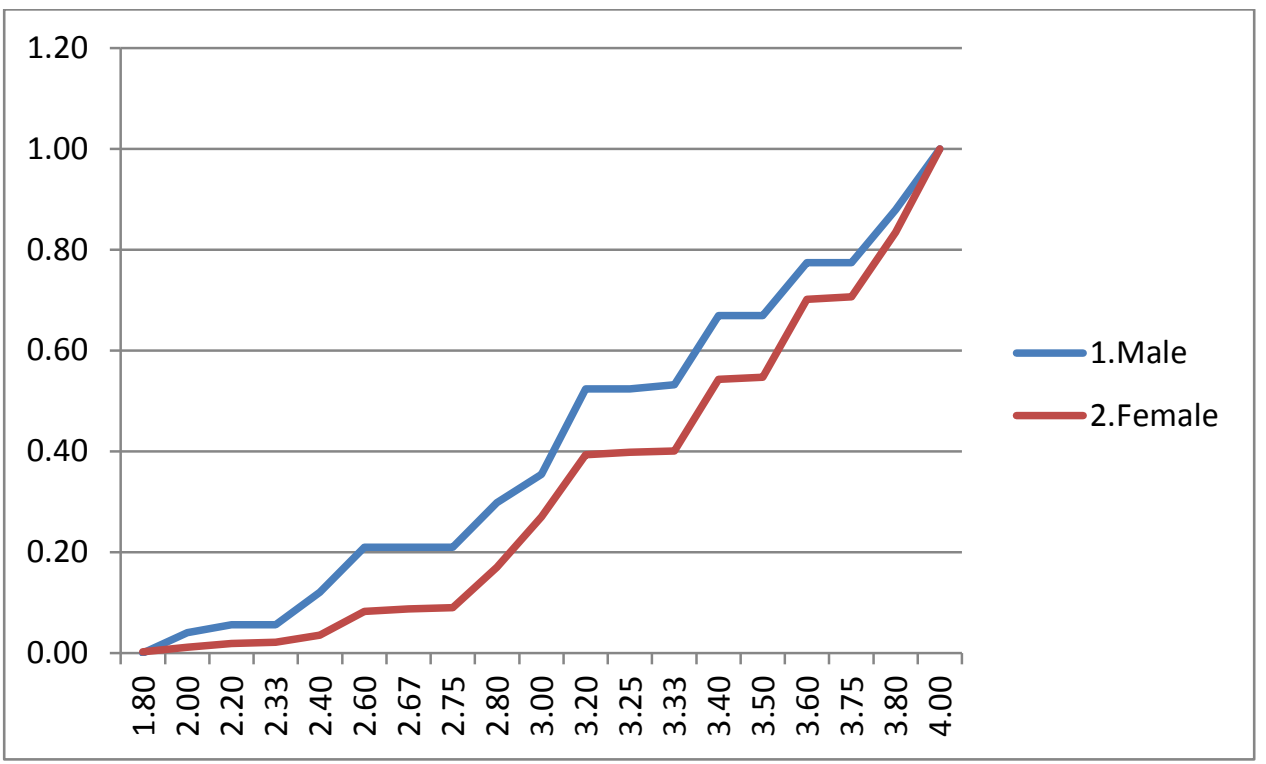


Openness

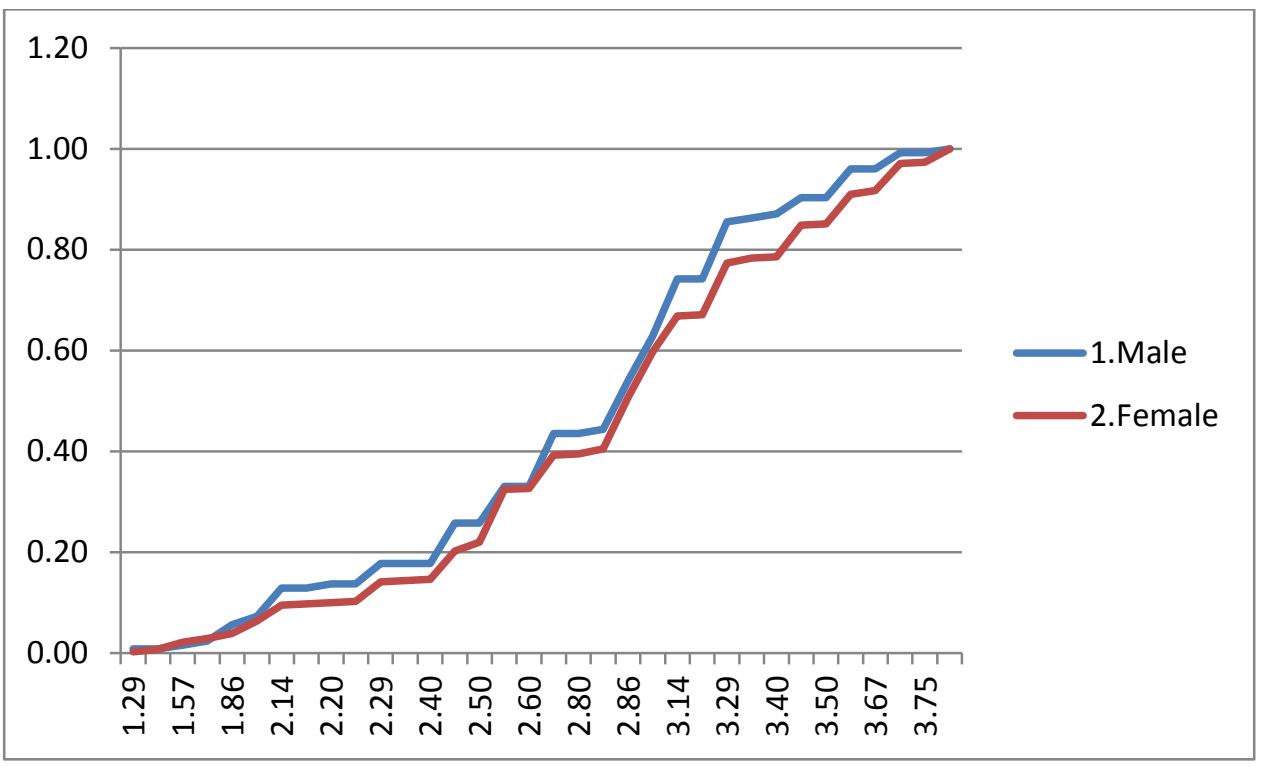


Table 1. Economic preparation for retirement: percent adequately prepared

\begin{tabular}{lrrrrr}
\hline \multicolumn{5}{c}{ Education } \\
\hline Couples & < high school & high school & some college & college & all \\
\cline { 2 - 6 } Male & 70.2 & 77.2 & 77.2 & 86.5 & 77.9 \\
Female & 69.9 & 80.8 & 82.6 & 90.2 & 81.1 \\
Total & 70.1 & 79.5 & 80.7 & 88.5 & 79.9 \\
Singles & & & & & \\
Male & 63.6 & 66.7 & 62.5 & 65.0 & 64.9 \\
Female & 29.0 & 60.5 & 51.0 & 69.6 & 51.3 \\
Total & 36.0 & 62.1 & 53.8 & 68.5 & 54.5 \\
\hline
\end{tabular}

Table 2. Probit estimates of the effect of personality traits on the probability of economic preparation for retirement. Married persons

\begin{tabular}{|c|c|c|c|c|c|c|c|c|c|}
\hline & \multicolumn{3}{|c|}{ All } & \multicolumn{3}{|c|}{ males } & \multicolumn{3}{|c|}{ females } \\
\hline & $\begin{array}{c}\text { co- } \\
\text { efficient }\end{array}$ & $\begin{array}{l}\text { marginal } \\
\text { effect }\end{array}$ & $p$-value & $\begin{array}{c}\text { co- } \\
\text { efficient }\end{array}$ & $\begin{array}{l}\text { marginal } \\
\text { effect }\end{array}$ & $\begin{array}{l}\mathrm{p}- \\
\text { value }\end{array}$ & $\begin{array}{c}\text { co- } \\
\text { efficient }\end{array}$ & $\begin{array}{l}\text { marginal } \\
\text { effect }\end{array}$ & $\begin{array}{l}p- \\
\text { value }\end{array}$ \\
\hline neuroticism & -0.186 & -0.051 & 0.026 & 0.069 & 0.020 & 0.616 & -0.372 & -0.096 & 0.001 \\
\hline extroversion & -0.096 & -0.026 & 0.424 & -0.331 & -0.095 & 0.097 & 0.072 & 0.019 & 0.645 \\
\hline agreeableness & -0.066 & -0.018 & 0.633 & -0.201 & -0.058 & 0.352 & 0.007 & 0.002 & 0.972 \\
\hline conscientiousness & 0.285 & 0.078 & 0.022 & 0.588 & 0.169 & 0.005 & 0.044 & 0.011 & 0.786 \\
\hline openness & 0.013 & 0.003 & 0.910 & -0.040 & -0.012 & 0.833 & 0.013 & 0.003 & 0.925 \\
\hline constant & 0.793 & & 0.128 & 0.558 & & 0.49 & 1.25 & & 0.093 \\
\hline observations & 949 & & & 357 & & & 592 & & \\
\hline
\end{tabular}

Note: The columns labeled "coefficient" show the estimated coefficients from the probit estimation. The columns labeled "marginal effect" show that change in the probability of adequate preparation associated with a one unit change in a personality trait. 
Table 3. Probit estimates of the effect of personality traits on the probability of economic preparation for retirement. Married persons. Education included.

\begin{tabular}{|c|c|c|c|c|c|c|c|c|c|}
\hline & \multicolumn{3}{|c|}{ All } & \multicolumn{3}{|c|}{ males } & \multicolumn{3}{|c|}{ females } \\
\hline & $\begin{array}{c}\text { co- } \\
\text { efficient }\end{array}$ & $\begin{array}{l}\text { marginal } \\
\text { effect }\end{array}$ & $p$-value & $\begin{array}{c}\text { co- } \\
\text { efficient }\end{array}$ & $\begin{array}{l}\text { marginal } \\
\text { effect }\end{array}$ & $\begin{array}{l}\mathrm{p}- \\
\text { value }\end{array}$ & $\begin{array}{c}\text { co- } \\
\text { efficient }\end{array}$ & $\begin{array}{l}\text { marginal } \\
\text { effect }\end{array}$ & $\begin{array}{l}\mathrm{p}- \\
\text { value }\end{array}$ \\
\hline neuroticism & -0.176 & -0.048 & 0.036 & 0.052 & 0.015 & 0.707 & -0.343 & -0.087 & 0.002 \\
\hline extroversion & -0.081 & -0.022 & 0.507 & -0.327 & -0.094 & 0.103 & 0.089 & 0.023 & 0.574 \\
\hline agreeableness & -0.029 & -0.008 & 0.835 & -0.154 & -0.044 & 0.482 & 0.027 & 0.007 & 0.896 \\
\hline conscientiousness & 0.222 & 0.060 & 0.081 & 0.480 & 0.137 & 0.026 & 0.025 & 0.006 & 0.881 \\
\hline openness & -0.078 & -0.021 & 0.493 & -0.101 & -0.029 & 0.602 & -0.090 & -0.023 & 0.532 \\
\hline high school & 0.304 & 0.081 & 0.021 & 0.217 & 0.061 & 0.297 & 0.331 & 0.083 & 0.056 \\
\hline some college & 0.300 & 0.074 & 0.051 & 0.216 & 0.058 & 0.377 & 0.318 & 0.074 & 0.116 \\
\hline college+ & 0.691 & 0.151 & 0.000 & 0.528 & 0.133 & 0.040 & 0.788 & 0.152 & 0.001 \\
\hline constant & 0.760 & & 0.149 & 0.721 & & 0.378 & 1.093 & & 0.149 \\
\hline observations & 949 & & & 357 & & & 592 & & \\
\hline
\end{tabular}

Note: The columns labeled "coefficient" show the estimated coefficients from the probit estimation.

The columns labeled "marginal effect" show that change in the probability of adequate preparation associated with a one unit change in a personality trait or education level.

Table 4. Probit estimates of the effect of personality traits on the probability of economic preparation for retirement. Single persons

\begin{tabular}{|c|c|c|c|c|c|c|c|c|c|}
\hline & \multicolumn{3}{|c|}{ All } & \multicolumn{3}{|c|}{ males } & \multicolumn{3}{|c|}{ females } \\
\hline & $\begin{array}{c}\text { co- } \\
\text { efficient }\end{array}$ & $\begin{array}{l}\text { marginal } \\
\text { effect }\end{array}$ & $p$-value & $\begin{array}{c}\text { co- } \\
\text { efficient }\end{array}$ & $\begin{array}{l}\text { marginal } \\
\text { effect }\end{array}$ & $\begin{array}{l}p- \\
\text { value }\end{array}$ & $\begin{array}{c}\text { co- } \\
\text { efficient }\end{array}$ & $\begin{array}{l}\text { marginal } \\
\text { effect }\end{array}$ & $\begin{array}{l}\mathrm{p}- \\
\text { value }\end{array}$ \\
\hline neuroticism & -0.203 & -0.080 & 0.034 & -0.253 & -0.086 & 0.212 & -0.158 & -0.063 & -0.203 \\
\hline extroversion & -0.267 & -0.105 & 0.044 & -0.591 & -0.202 & 0.039 & -0.206 & -0.082 & -0.267 \\
\hline agreeableness & -0.210 & -0.083 & 0.146 & 0.004 & 0.001 & 0.988 & -0.121 & -0.048 & -0.210 \\
\hline conscientiousness & 0.066 & 0.026 & 0.615 & 0.221 & 0.076 & 0.423 & 0.086 & 0.034 & 0.066 \\
\hline openness & 0.184 & 0.072 & 0.132 & 0.195 & 0.067 & 0.508 & 0.150 & 0.060 & 0.184 \\
\hline constant & 1.408 & & 0.013 & 1.609 & & 0.112 & 0.738 & & 0.309 \\
\hline observations & 542 & & & 124 & & & 418 & & \\
\hline
\end{tabular}

Note: The columns labeled "coefficient" show the estimated coefficients from the probit estimation.

The columns labeled "marginal effect" show that change in the probability of adequate preparation associated with a one unit change in a personality trait. 
Table 5. Probit estimates of the effect of personality traits on the probability of economic preparation for retirement. Single persons. Education included.

\begin{tabular}{|c|c|c|c|c|c|c|c|c|c|}
\hline & \multicolumn{3}{|c|}{ All } & \multicolumn{3}{|c|}{ males } & \multicolumn{3}{|c|}{ females } \\
\hline & $\begin{array}{c}\text { co- } \\
\text { efficient }\end{array}$ & $\begin{array}{l}\text { marginal } \\
\text { effect }\end{array}$ & p-value & $\begin{array}{c}\text { co- } \\
\text { efficient }\end{array}$ & $\begin{array}{l}\text { marginal } \\
\text { effect }\end{array}$ & $\begin{array}{l}p- \\
\text { value }\end{array}$ & $\begin{array}{c}\text { co- } \\
\text { efficient }\end{array}$ & $\begin{array}{l}\text { marginal } \\
\text { effect }\end{array}$ & $\begin{array}{l}\mathrm{p}- \\
\text { value }\end{array}$ \\
\hline neuroticism & -0.193 & -0.076 & 0.047 & -0.251 & -0.086 & 0.218 & -0.143 & -0.057 & 0.207 \\
\hline extroversion & -0.177 & -0.070 & 0.192 & -0.590 & -0.201 & 0.038 & -0.048 & -0.019 & 0.766 \\
\hline agreeableness & -0.189 & -0.075 & 0.195 & 0.026 & 0.009 & 0.927 & -0.129 & -0.052 & 0.492 \\
\hline conscientiousness & 0.026 & 0.010 & 0.843 & 0.221 & 0.076 & 0.430 & 0.028 & 0.011 & 0.856 \\
\hline openness & 0.045 & 0.018 & 0.732 & 0.158 & 0.054 & 0.616 & -0.052 & -0.021 & 0.732 \\
\hline high school & 0.673 & 0.257 & 0.000 & 0.203 & 0.069 & 0.518 & 0.816 & 0.314 & 0.000 \\
\hline some college & 0.423 & 0.161 & 0.013 & 0.167 & 0.055 & 0.659 & 0.535 & 0.207 & 0.006 \\
\hline college+ & 0.826 & 0.291 & 0.000 & 0.242 & 0.078 & 0.578 & 1.037 & 0.367 & 0.000 \\
\hline constant & 1.092 & & 0.057 & 1.482 & & 0.148 & 0.427 & & 0.564 \\
\hline observations & 542 & & & 124 & & & 418 & & \\
\hline
\end{tabular}

Note: The columns labeled "coefficient" show the estimated coefficients from the probit estimation. The columns labeled "marginal effect" show that change in the probability of adequate preparation associated with a one unit change in a personality trait or education level.

Table 6. Effect of personality traits on total economic resources. Married persons. Regression of log of total economic resources

\begin{tabular}{lrrrrrr} 
& \multicolumn{1}{c}{ All } & p-value & \multicolumn{1}{c}{ Males } & p-value & Females & \multicolumn{1}{c}{$p$-value } \\
\hline neuroticism & -0.102 & 0.040 & 0.106 & 0.218 & -0.238 & 0.000 \\
extroversion & -0.002 & 0.972 & -0.115 & 0.346 & 0.086 & 0.308 \\
agreeableness & -0.116 & 0.152 & -0.127 & 0.341 & -0.146 & 0.194 \\
conscientiousness & 0.407 & 0.000 & 0.624 & 0.000 & 0.246 & 0.006 \\
openness & 0.173 & 0.007 & 0.170 & 0.155 & 0.156 & 0.038 \\
constant & 12.330 & 0.000 & 11.540 & 0.000 & 13.060 & 0.000 \\
observations & 949 & & 357 & & 592 & \\
\hline
\end{tabular}


Table 7. Effect of personality traits on total economic resources. Married persons. Regression of log of total economic resources. Education included.

\begin{tabular}{lrrrrrr} 
& \multicolumn{1}{c}{ All } & p-value & \multicolumn{1}{c}{ Males } & p-value & Females & p-value \\
\hline neuroticism & -0.068 & 0.131 & 0.067 & 0.394 & -0.162 & 0.003 \\
extroversion & 0.024 & 0.701 & -0.100 & 0.367 & 0.108 & 0.163 \\
agreeableness & -0.015 & 0.846 & 0.010 & 0.935 & -0.085 & 0.409 \\
conscientiousness & 0.268 & 0.000 & 0.338 & 0.005 & 0.204 & 0.013 \\
openness & -0.006 & 0.926 & 0.017 & 0.880 & -0.020 & 0.779 \\
high school & 0.478 & 0.000 & 0.412 & 0.001 & 0.504 & 0.000 \\
some college & 0.747 & 0.000 & 0.707 & 0.000 & 0.747 & 0.000 \\
college+ & 1.211 & 0.000 & 1.182 & 0.000 & 1.199 & 0.000 \\
constant & 12.200 & 0.000 & 11.930 & 0.000 & 12.670 & 0.000 \\
observations & 949 & & 357 & & 592 & \\
\hline
\end{tabular}

Table 8. Effect of personality traits on total economic resources. Single persons. Regression of log of total economic resources

\begin{tabular}{lrrrrrr} 
& \multicolumn{1}{c}{ All } & p-value & \multicolumn{1}{c}{ Males } & p-value & Females & p-value \\
\hline neuroticism & -0.165 & 0.081 & -0.151 & 0.469 & -0.150 & 0.161 \\
extroversion & -0.217 & 0.100 & -0.276 & 0.340 & -0.219 & 0.147 \\
agreeableness & -0.133 & 0.353 & -0.046 & 0.874 & -0.058 & 0.745 \\
conscientiousness & 0.305 & 0.018 & 0.323 & 0.229 & 0.331 & 0.028 \\
openness & 0.376 & 0.002 & 0.199 & 0.498 & 0.405 & 0.003 \\
constant & 11.930 & 0.000 & 12.380 & 0.000 & 11.420 & 0.000 \\
observations & 537 & & 123 & & 414 & \\
\hline
\end{tabular}

Table 9. Effect of personality traits on total economic resources. Single persons. Regression of log of total economic resources. Education included.

\begin{tabular}{lrrrrrr} 
& \multicolumn{1}{c}{ All } & p-value & \multicolumn{1}{c}{ Males } & p-value & Females & $p$-value \\
\hline neuroticism & -0.113 & 0.183 & -0.116 & 0.556 & -0.078 & 0.410 \\
extroversion & -0.023 & 0.849 & -0.317 & 0.245 & 0.060 & 0.657 \\
agreeableness & -0.056 & 0.663 & 0.105 & 0.698 & -0.014 & 0.932 \\
conscientiousness & 0.233 & 0.044 & 0.376 & 0.141 & 0.212 & 0.111 \\
openness & -0.015 & 0.896 & -0.104 & 0.720 & -0.027 & 0.830 \\
high school & 1.079 & 0.000 & 0.956 & 0.002 & 1.116 & 0.000 \\
some college & 1.254 & 0.000 & 0.997 & 0.006 & 1.350 & 0.000 \\
college+ & 1.787 & 0.000 & 1.704 & 0.000 & 1.847 & 0.000 \\
constant & 11.360 & 0.000 & 11.780 & 0.000 & 10.890 & 0.000 \\
observations & 537 & & 123 & & 414 & \\
\hline
\end{tabular}


Table 10. Effect of personality traits on initial spending. Married persons. Regression of log of initial spending.

\begin{tabular}{lllllll} 
& All & p-value & Males & p-value & Females & p-value \\
\hline neuroticism & -0.017 & 0.552 & 0.089 & 0.064 & -0.082 & 0.026 \\
extroversion & -0.018 & 0.659 & -0.046 & 0.494 & 0.008 & 0.872 \\
agreeableness & -0.029 & 0.543 & -0.020 & 0.785 & -0.016 & 0.817 \\
conscientiousness & 0.170 & 0.000 & 0.289 & 0.000 & 0.090 & 0.100 \\
openness & 0.130 & 0.001 & 0.152 & 0.023 & 0.103 & 0.024 \\
constant & 9.866 & 0.000 & 9.269 & 0.000 & 10.210 & 0.000 \\
observations & 949 & & 357 & & 592 & \\
\hline
\end{tabular}

Table 11. Effect of personality traits on initial spending. Married persons. Regression of log of initial spending. Education included

\begin{tabular}{lllllll} 
& All & p-value & Males & p-value & Females & p-value \\
\hline neuroticism & 0.000 & 1.000 & 0.069 & 0.121 & -0.040 & 0.241 \\
extroversion & -0.005 & 0.905 & -0.039 & 0.532 & 0.019 & 0.694 \\
agreeableness & 0.029 & 0.512 & 0.048 & 0.492 & 0.026 & 0.691 \\
conscientiousness & 0.096 & 0.017 & 0.147 & 0.032 & 0.065 & 0.205 \\
openness & 0.034 & 0.346 & 0.075 & 0.234 & 0.004 & 0.923 \\
high school & 0.199 & 0.000 & 0.199 & 0.005 & 0.197 & 0.001 \\
some college & 0.390 & 0.000 & 0.377 & 0.000 & 0.390 & 0.000 \\
college+ & 0.615 & 0.000 & 0.581 & 0.000 & 0.622 & 0.000 \\
constant & 9.822 & 0.000 & 9.463 & 0.000 & 10.030 & 0.000 \\
observations & 949 & & 357 & & 592 & \\
\hline
\end{tabular}

Table 12. Effect of personality traits on initial spending. Married persons. Regression of log of initial spending. Education and economic resources included.

\begin{tabular}{lllllll} 
& All & p-value & Males & p-value & Females & p-value \\
\hline neuroticism & 0.022 & 0.335 & 0.050 & 0.195 & 0.017 & 0.565 \\
extroversion & -0.012 & 0.699 & -0.011 & 0.845 & -0.019 & 0.635 \\
agreeableness & 0.034 & 0.367 & 0.045 & 0.455 & 0.055 & 0.298 \\
conscientiousness & 0.010 & 0.768 & 0.050 & 0.399 & -0.007 & 0.874 \\
openness & 0.035 & 0.239 & 0.070 & 0.197 & 0.011 & 0.758 \\
log total resources & 0.321 & 0.000 & 0.286 & 0.000 & 0.350 & 0.000 \\
high school & 0.045 & 0.236 & 0.082 & 0.191 & 0.021 & 0.674 \\
some college & 0.150 & 0.001 & 0.175 & 0.018 & 0.128 & 0.024 \\
college+ & 0.227 & 0.000 & 0.243 & 0.002 & 0.203 & 0.002 \\
constant & 5.905 & 0.000 & 6.050 & 0.000 & 5.598 & 0.000 \\
observations & 949 & & 357 & & 592 & \\
\hline
\end{tabular}


Table 13. Effect of personality traits on initial spending. Single persons. Regression of log of initial spending

\begin{tabular}{lllllll} 
& All & $p$-value & Males & $p$-value & Females & $p$-value \\
\hline neuroticism & -0.065 & 0.125 & -0.009 & 0.907 & -0.086 & 0.088 \\
extroversion & -0.071 & 0.226 & -0.037 & 0.742 & -0.085 & 0.226 \\
agreeableness & -0.032 & 0.618 & 0.006 & 0.960 & -0.054 & 0.518 \\
conscientiousness & 0.104 & 0.071 & 0.091 & 0.382 & 0.109 & 0.120 \\
openness & 0.211 & 0.000 & 0.192 & 0.095 & 0.214 & 0.001 \\
constant & 9.633 & 0.000 & 9.392 & 0.000 & 9.771 & 0.000 \\
observations & 537 & & 123 & & 414 & \\
\hline
\end{tabular}

Table 14. Effect of personality traits on initial spending. Single persons. Regression of log of initial spending. Education included

\begin{tabular}{lllllll} 
& All & $p$-value & Males & $p$-value & Females & $p$-value \\
\hline neuroticism & -0.045 & 0.255 & 0.008 & 0.915 & -0.060 & 0.200 \\
extroversion & 0.006 & 0.908 & -0.056 & 0.605 & 0.029 & 0.666 \\
agreeableness & -0.010 & 0.865 & 0.063 & 0.564 & -0.053 & 0.498 \\
conscientiousness & 0.080 & 0.139 & 0.124 & 0.224 & 0.062 & 0.345 \\
openness & 0.045 & 0.406 & 0.073 & 0.530 & 0.030 & 0.633 \\
high school & 0.259 & 0.000 & 0.198 & 0.098 & 0.279 & 0.000 \\
some college & 0.393 & 0.000 & 0.264 & 0.067 & 0.433 & 0.000 \\
college+ & 0.688 & 0.000 & 0.624 & 0.000 & 0.717 & 0.000 \\
constant & 9.552 & 0.000 & 9.242 & 0.000 & 9.747 & 0.000 \\
observations & 537 & & 123 & & 414 & \\
\hline
\end{tabular}

Table 15. Effect of personality traits on initial spending. Single persons. Regression of log of initial spending. Education and economic resources included.

\begin{tabular}{lllllll} 
& All & p-value & Males & $p$-value & Females & $p$-value \\
\hline neuroticism & -0.025 & 0.502 & 0.023 & 0.764 & -0.044 & 0.303 \\
extroversion & 0.011 & 0.837 & -0.018 & 0.867 & 0.017 & 0.786 \\
agreeableness & 0.000 & 0.999 & 0.050 & 0.632 & -0.050 & 0.481 \\
conscientiousness & 0.038 & 0.451 & 0.078 & 0.428 & 0.018 & 0.759 \\
openness & 0.047 & 0.340 & 0.086 & 0.441 & 0.035 & 0.533 \\
log total resources & 0.181 & 0.000 & 0.122 & 0.001 & 0.205 & 0.000 \\
high school & 0.063 & 0.275 & 0.081 & 0.495 & 0.050 & 0.453 \\
some college & 0.166 & 0.016 & 0.142 & 0.317 & 0.157 & 0.050 \\
college+ & 0.364 & 0.000 & 0.416 & 0.015 & 0.338 & 0.000 \\
constant & 7.497 & 0.000 & 7.803 & 0.000 & 7.519 & 0.000 \\
observations & 537 & & 123 & & 414 & \\
\hline
\end{tabular}


Table 16. Summary of effects of personality traits on log economic resources (total wealth) and on log spending. Married persons. Without and with education.

\begin{tabular}{|c|c|c|c|c|c|c|}
\hline & \multicolumn{3}{|c|}{ males } & \multicolumn{3}{|c|}{ females } \\
\hline & spending & wealth & $\begin{array}{r}\text { spending- } \\
\text { wealth }\end{array}$ & spending & wealth & $\begin{array}{r}\text { spending- } \\
\text { wealth }\end{array}$ \\
\hline \multicolumn{7}{|l|}{ without education } \\
\hline neuroticism & 0.089 & 0.106 & -0.017 & -0.082 & -0.238 & $0.156 *$ \\
\hline extroversion & -0.046 & -0.115 & 0.069 & 0.008 & 0.086 & -0.078 \\
\hline agreeableness & -0.020 & -0.127 & 0.107 & -0.016 & -0.146 & 0.130 \\
\hline conscientiousness & 0.289 & 0.624 & $-0.335^{*}$ & 0.090 & 0.246 & -0.156 \\
\hline openness & 0.152 & 0.170 & -0.018 & 0.103 & 0.156 & -0.053 \\
\hline \multicolumn{7}{|l|}{ With education } \\
\hline neuroticism & 0.069 & 0.067 & 0.002 & -0.040 & -0.162 & $0.122 \#$ \\
\hline extroversion & -0.039 & -0.100 & 0.061 & 0.019 & 0.108 & -0.089 \\
\hline agreeableness & 0.048 & 0.010 & 0.038 & 0.026 & -0.085 & 0.111 \\
\hline conscientiousness & 0.147 & 0.338 & -0.191 & 0.065 & 0.204 & -0.139 \\
\hline openness & 0.075 & 0.017 & 0.058 & 0.004 & -0.020 & 0.024 \\
\hline
\end{tabular}

Note: "spending - wealth" is the difference between the entries in the "spending" and the "wealth" columns. *Significant at $5 \%$ level. \#Significant at $10 \%$ level.

Table 17. Effects of personality traits on log economic resources (total wealth) and on log spending. Single persons. Without and with education

\begin{tabular}{lrrrrrr}
\hline & \multicolumn{3}{c}{ males } & \multicolumn{3}{c}{ females } \\
\cline { 2 - 7 } & spending & wealth & $\begin{array}{r}\text { spending- } \\
\text { wealth }\end{array}$ & spending & wealth & $\begin{array}{r}\text { spending- } \\
\text { wealth }\end{array}$ \\
\cline { 2 - 7 } without education & & & & & \\
neuroticism & -0.009 & -0.151 & 0.142 & -0.086 & -0.150 & 0.064 \\
extroversion & -0.037 & -0.276 & 0.239 & -0.085 & -0.219 & 0.134 \\
agreeableness & 0.006 & -0.046 & 0.052 & -0.054 & -0.058 & 0.004 \\
conscientiousness & 0.091 & 0.323 & -0.232 & 0.109 & 0.331 & -0.222 \\
openness & 0.192 & 0.199 & -0.007 & 0.214 & 0.405 & -0.191 \\
with education & & & & & & \\
neuroticism & 0.008 & -0.116 & 0.124 & -0.060 & -0.078 & 0.018 \\
extroversion & -0.056 & -0.317 & 0.261 & 0.029 & 0.060 & -0.031 \\
agreeableness & 0.063 & 0.105 & -0.042 & -0.053 & -0.014 & -0.039 \\
conscientiousness & 0.124 & 0.376 & -0.252 & 0.062 & 0.212 & -0.150 \\
openness & 0.073 & -0.104 & 0.177 & 0.030 & -0.027 & 0.057 \\
\hline
\end{tabular}

Note: "spending - wealth" is the difference between the entries in the "spending" and the "wealth" columns 